DOI: 10.32844/2222-5374-2020-104-2.41

УДК: 343.1

Конюшенко Я. Ю.,

доцент кафедри кримінального процесу

Національної академії внутрішніх справ, кандидат юридичних наук, дощент

\title{
ВІДОМЧИЙ КОНТРОЛЬ В СИСТЕМІ ГАРАНТІЙ ПРАВ ОСОБИ ПІД ЧАС ПРОВЕДЕННЯ СЛІДЧИХ (РОЗШУКОВИХ) ДІЙ
}

В статті визначено доктринальні підходи до поняття «забезпечення прав і свобод людини». Встановлено, що сфера кримінального провадження $\epsilon$ такою, вякійнайбільшзвужуютьсятаможутьбутипорушеніконституційні права і свободи особи, оскільки діяльність органів досудового розслідування пов'язана із застосуванням обмежень правлюдини таувизначених випадках. Виходячи з цього, запропоновано визначати забезпечення прав $і$ свобод людини в сфері кримінального провадження як діяльність уповноважених органів (органи досудового розслідування, прокуратура, суд), спрямовану на недопущення порушень прав і свобод кожного учасника кримінального провадження, контроль за додержанням прав людини та захист порушених прав. Щодо визначення гарантій прав учасників кримінального провадження під час проведення слідчих (розшукових) дій, автор дійшов висновку про те, що вони є складовою частиною гарантій кримінального провадження в цілому. Такі гарантії спрямовані на забезпечення виконання завдань кримінального провадження, реалізацію його засад, додержання належної правової процедури та недопущення порушень прав і свобод учасників слідчої (розшукової) дії та в необхідних випадках сприяють відновленню порушених прав учасників кримінального провадження. Розглянуто відомчий контроль за проведенням слідчих (розшукових) дій як одну $з$ основних гарантій забезпечення прав, свобод та законних інтересів особи. Запропоновано визначати відомчий контроль як управлінську функцію керівників органів дізнання або досудового розслідування з метою виконання завдань кримінального провадження, додержання прав і свобод учасників дізнання та досудового розслідування, визначення законності дій слідчого або дізнавача, а також недоліків у здійсненні досудового розслідування $з$ метою якнайшвидшого їх усунення. Окреслено ряд проблемних питань під час здійснення відомчого контролю за проведенням дізнавачем та слідчим слідчих (розшукових) дій, зокрема, щодо надання вказівок, витребування матеріалів кримінального провадження керівником органу дізнання або досудового розслідування вищого рівня, співвідношення повноважень слідчого та керівника органу досудового розслідування. На підставі проведеного дослідження запропоновано внесення змін до Кримінального процесуального кодексу України.

Ключові слова: відомчий контроль; слідчі (розшукові) дї; забезпечення прав і свобод людини; гарантії забезпечення прав, свобод та законних інтересів особи. 
Актуальність теми. На виконання основних міжнародних документів у сфері захисту прав людини ч. 2 ст. 3 Конституції України визначено, що права і свободи людини та їх гарантії визначають зміст і спрямованість діяльності держави. Держава відповідає перед людиною за свою діяльність. Утвердження і забезпечення прав і свобод людини є головним обов'язком держави [1]. Безумовно, сфера кримінального провадження $\epsilon$ такою, в якій конституційні права людини можуть бути обмежені в найбільшій мірі. Тому на теперішній час вельми актуальним $є$ вдосконалення існуючого механізму захисту прав людини під час досудового розслідування, в тому числі при проведенні слідчих (розшукових) дій.

Аналіз останніх досліджень і публікацій. Питанню відомчого контролю в доктрині кримінального процесу приділено значну увагу такими науковцями, як О.В. Баулін, І.В. Бондаренко, І.В. Гловюк, Г.Р. Колеснік, Р.Ю. Савонюк, А.Б. Степанов, X.С. Таджиєв, B.I. Фаринник, I.I. Цирюлик, O.O. Юхно тощо. Разом із цим, дослідження відомчого контролю з позиції гарантії додержання прав і свобод людини під час проведення слідчих (розшукових) дій $\epsilon$ недостатньо вивченим и потребує поглибленого дослідження.

Метою наукової статті є визначення відомчого контролю за слідчими (розшуковими) діями як гарантії додержання прав людини, виокремлення проблемних питань, що виникають під час його здійснення.

Виклад основного матеріалу. Поняття «забезпечення прав людини» має дискусійний характер та розглядається в правовій доктрині в різних аспектах. Термін «забезпечення» має досить широке значення і трактується як надання (постачання) чогось кимось у достатній кількості, створення усіх необхідних умов для здійснення чого-небудь; гарантувати щось; захищати, охороняти когось, що-небудь [2, с. 273].

В теорії держави та права забезпечення прав людини розглядається як система їх гарантування. Так, під забезпеченням прав і свобод розуміється система загальних (політичних, економічних, духовних та ін.) і спеціально юридичних засобів та інститутів, спрямованих на створення умов для реалізації прав людини, а також забезпечення їх всебічної охорони та захисту від порушень [3, с. 456].

Найбільш прийнятною вважаємо наукову позицію П.М. Рабиновича щодо того, що забезпечення прав і свобод людини - це створення умов для здійснення зазначених прав і свобод людини, яке включає такі три елементи державної діяльності: сприяння для здійснення прав і свобод людини ; охорона прав і свобод людини ; захист прав і свобод людини (відновлення порушення правомірного стану, притягнення порушників до відповідальності) [4, с. 45].

Сфера кримінального провадження, безумовно, $\epsilon$ такою, в якій найбільш звужуються та можуть бути порушені конституційні права і свободи особи. Діяльність органів досудового розслідування пов'язана із застосуванням обмежень прав людини та у визначених випадках - із застосуванням заходів процесуального примусу. Тому саме в цій сфері найбільш актуальним $€$ забезпечення прав і свобод учасників кримінального провадження.

Виходячи 3 цього, вважаємо, забезпечення прав і свобод людини в сфері кримінального провадження - це діяльність уповноважених органів 
(органи досудового розслідування, прокуратура, суд), спрямована на недопущення порушень прав і свобод кожного учасника кримінального провадження, контроль за додержанням прав людини та захист порушених прав. Зазначені дії забезпечуються шляхом застосування певних юридичних гарантій, під якими, як правило, розуміють систему закріплених правовими нормами юридичних засобів, яка здатна реально забезпечити реалізацію, охорону та захист суб'єктивних прав особи [5, c. 108].

Щодо безпосередньо гарантій забезпечення прав людини, зазначимо, що сам по собі зазначений термін означає поруку в чомусь, забезпечення чого-небудь [6, с. 29].У Великому тлумачному словнику сучасної української мови юридичні гарантії визначаються як законодавчо закріплені засоби охорони прав і свобод громадян, способи їх реалізації, а також засоби охорони правопорядку, інтересів суспільства і держави [7, с. 173].

На думку М.С. Строговича, юридичні гарантії - це ті встановлені законом та нормами права засоби і способи, якими охороняються та захищаються права громадян, припиняються та усуваються порушені права [8, с. 180-181].

Як слушно зазначає М.А. Погорецький, кримінально-процесуальні гарантії $€$ фундаментальною категорією кримінального процесу. Вони мають не лише науково-методологічне значення для розробки засад кримінального судочинства, а й практичне значення для забезпечення функціонування усіх його інститутів, його окремих норм, реалізації процесуальних прав та законних інтересів усіх його субьєктів [9, с. 1].

В доктрині кримінального процесу кримінально-процесуальні гарантії розглядаються як: 1) спеціальні правові засоби, що забезпечують реалізацію прав та законних інтересів учасників кримінального провадження, а також виконання ними своїх обов'язків [10, с. 15]; 2) засоби, що встановлені кримінально-процесуальними нормами для здійснення завдань кримінального судочинства, насамперед захисту прав і законних інтересів осіб, що притягаються до кримінальної відповідальності [11, c. 21]; 3) визначені кримінальним процесуальним законом засоби та способи, спрямовані на реалізацію прав та обов'язків усіх суб'єктів кримінального процесу, забезпечення реалізації їх законних інтересів, а також на досягнення мети та виконання завдань кримінального судочинства [9, с. 16]; 4) встановлені законом засоби і способи, що сприяють успішному здійсненню правосуддя, захисту прав і законних інтересів особистості [12, с. 59]; 6) різновид юридичних (правових) гарантій, внутрішньодержавних за сферою діяльності, галузевих за способом регулювання, які є запорукою встановлення об'єктивної істини, забезпечення процесуальних прав, цивільно-правових та кримінальноправових інтересів особи у кримінальному судочинстві, а також складові елементи зазначеного поняття [13, с. 4]; 7) форма втілення в реальність матеріальних гарантій $[14$, с. 8] тощо. Зазначені наукові позиції стосуються визначення кримінально-процесуальних гарантій в цілому.

Якщо розглядати зазначене поняття через призму інтересів учасників кримінального провадження, доцільно навести такі його визначення як: 1) встановлені нормами кримінального процесуального закону різні за 
своїм конкретним змістом засоби, які в своїй сукупності забезпечують учасникам процесу можливість реалізовувати надані їм права [15, с. 133]; 2) гарантії прав та інтересів особи, разом із гарантіями ефективної діяльності органів, які ведуть кримінальний процес, у своїй сукупності утворюють засоби ефективного функціонування кримінального процесу в цілому [16, с. 38].

Гарантії прав учасників кримінального провадження під час проведення слідчих (розшукових) дій $є$ складовою частиною гарантій кримінального провадження в цілому. Вони спрямовані на забезпечення виконання завдань кримінального провадження, реалізацію його засад, додержання належної правової процедури та недопущення порушень прав і свобод учасників слідчої (розшукової) дії та в необхідних випадків сприяють відновленню порушених прав учасників кримінального провадження.

Дослідження положень КПК України вказує на те, що в системі кримінального судочинства під час проведення слідчих (розшукових) дій гарантами додержання прав і свободучасників кримінальногопровадження є: керівник органу досудового розслідування, прокурор, слідчий суддя, відповідно, правовими гарантіями забезпечення прав, свобод та законних інтересів особи під час проведення слідчих (розшукових) дій є відомчий контроль, нагляд прокурора та судовий контроль за їх проведенням.

Вважаємо, першим «щаблем» реалізації зазначених гарантій виступає відомчий контроль, однак у чинному законодавстві України поняття «відомчий контроль» не розкривається. Загалом, термін «контроль» походить від франц. «controlle», що означає «повернення до раніше розглянутого питання». Словник української мови тлумачить його як «перевірка, облік діяльності кого-, чого-небудь, нагляд за кимось, чимось» $[17$, с. 271$]$.

В доктрині кримінального процесу відомчий контроль у досудовому розслідуванні визначається як додаткова, внутрішня функція конкретного органу досудового розслідування, що виконується уповноваженими ним посадовими особами - керівниками слідчих органів відповідного рівня на професійній основі, які в умовах значного обсягу слідчої діяльності та ускладнення її новими видами кримінальних правопорушень та новими способами їх вчинення шляхом реалізації всього арсеналу наданих їм організаційно-управлінських і організаційно-процесуальних повноважень, забезпечують максимальну мобілізацію зусиль підпорядкованого персоналу слідчих на підвищення інтенсифікації, результативності та якості слідчої роботи [18, с. 75]. Також, відомчий контроль за діяльністю слідчих розглядається як складова організаційної діяльності керівника органу досудового розслідування. Іншими словами, контроль - процес забезпечення досягнення організацією своєї мети, що складається зі встановлення критеріїв, визначення фактично досягнутих результатів і запровадження корективів у тому випадку, якщо досягнуті результати суттєво відрізняються від встановлених критеріїв [19, с. 293].

Серед науковців $\epsilon$ різні позиції щодо змісту й обсягів процесуальних функцій керівника органу досудового розслідування. Вивчення наукових праць щодо відомчого контрою з боку керівника органу досудового 
розслідування дозволяє дійти висновку про наявність в доктрині кримінального процесу двох діаметрально протилежних позицій: 1) перша полягає в обмеженні відомчого контролю та розширенні процесуальної самостійності слідчого під час проведення слідчих (розшукових) дій; 2) друга, навпаки, передбачає широкі повноваження керівника органу досудового розслідування або органу дізнання.

В аспекті дослідження суб'єктів відомчого контролю зазначимо, що відповідно до п. 8 ст. 3 КПК України, до керівників органів досудового розслідування належать: «начальник Головного слідчого управління, слідчого управління, відділу, відділення органу Національної поліції, органу безпеки, органу, що здійснює контроль за додержанням податкового законодавства, перший заступник або заступник Директора Державного бюро розслідувань, керівник (начальник) Головного слідчого управління, слідчого управління, відділу органу Державного бюро розслідувань, Головного підрозділу детективів, підрозділу детективів, відділу детективів, підрозділу внутрішнього контролю Національного антикорупційного бюро України та його заступники, які діють у межах своїх повноважень». В свою чергу, до керівників органів дізнання належать: «начальник підрозділу дізнання органу Національної поліції, органу безпеки, органу, що здійснює контроль за додержанням податкового законодавства, органу Державного бюро розслідувань, а в разі відсутності підрозділу дізнання керівник органу досудового розслідування» (п. 7-1 ст. 3 КПК України) [20]. Отже, суб'єктами здійснення відомчого контролю є начальники слідчих відділів, управлінь (підрозділів органів дізнання) відповідного рівня або вищих рівнів.

Щодо обсягу повноважень керівників органу досудового розслідування або органу дізнання як суб'єктів здійснення відомчого контролю, слід зазначити, що в доктрині кримінального процесу пропонується розподіляти їх на організаційні та процесуальні [21, с. 83]. Законодавчо вони визначені в ст.ст. 39, 39-1 КПК України, а також деталізовані у відомчих нормативних документах.

Вважаємо, повноваження керівника органу досудового розслідування щодо здійснення відомчого контролю за слідчими (розшуковими) діями можна розділити на організаційні та процесуальні. На нашу думку, до організаційних належать: 1) визначення слідчого (слідчих), який здійснюватиме досудове розслідування, (дізнавача - при проведенні дізнання), a у випадках здійснення досудового розслідування слідчою групою визначення старшого слідчої групи, який керуватиме діями інших слідчих; 2) відсторонення слідчого (дізнавача) від проведення досудового розслідування вмотивованою постановою за ініціативою прокурора або з власної ініціативи з наступним повідомленням прокурора та призначати іншого слідчого за наявності підстав, передбачених КПК України, для його відводу або у разі неефективного досудового розслідування.

Погоджуємося 3 науковою думкою, що правильна організація досудового розслідування, засоби їх здійснення, їх найбільш оптимальний набір та послідовність реалізації дозволяють керівнику органу досудового розслідування забезпечити правильне встановлення всіх обставин вчиненого кримінального правопорушення. Разом 3 цим, процедуру 
організації розслідування по кожному кримінальному правопорушенню забезпечити на нормативному рівніу повномуобсязі практично неможливо, тому навіть у підзаконних актах організаційно-управлінський процес визначається у загальному плані. Загальними, типовими елементами організаційно-управлінської діяльності керівника органу досудового розслідування є: добір, розстановка, виховання кадрів та забезпечення підвищення їх кваліфікації; своєчасне та правильне визначення завдань перед підлеглими; здійснення дієвого контролю за своєчасним і якісним розслідуванням кримінальних правопорушень; матеріальне, технічне, методичне і правове забезпечення слідчої діяльності; належна постановка інформаційно-аналітичної діяльності, обліку і звітності [22, с. 150; 18, c. 236].

До процесуальних повноважень, на нашу думку, належать: 1) ознайомлення з матеріалами досудового розслідування (дізнання), надання слідчому (дізнавачу) письмових вказівок, які не можуть суперечити рішенням та вказівкам прокурора; 2) погодження проведення слідчих (розшукових) дій та продовження строку їх проведення у випадках, передбачених КПК України; 3) здійснення досудового розслідування (дізнання), користуючись при цьому повноваженнями слідчого (дізнавача).

Як слушно зазначає А.Б. Степанов, суто процесуальними слід визнавати ті повноваження, які пов'язані із безпосереднім впливом на хід досудового розслідування у конкретному кримінальному провадженні. Ті ж з повноважень, що передбачені у ч. 2 ст. 39 КПК, здійснення яких спрямоване на забезпечення належного рівня роботи слідчого, є суто організаційними [21, с. 85].

Одним із найбільш дискусійних повноважень керівника органу досудового розслідування $\epsilon$ надання слідчому письмових вказівок, в тому числі й стосовно проведення слідчих (розшукових) дій. Так, з одного боку це дозволяє визначити напрямки здійснення досудового розслідування, правильно організувати та скоординувати роботу слідчого, сприяє додержанню прав і свобод учасників кримінального провадження, усунути прогалини та порушення під час досудового розслідування. Але, з іншого боку, це обмежує процесуальну самостійність слідчого. Адже, як зазначено в п. 4 р. 1 Інструкції з організації діяльності слідчих підрозділів Національної поліції України, затвердженої наказом МВС України від 06.07.2017 № 570, працівникам інших органів та підрозділів поліції забороняється у будь-який спосіб утручатися в процесуальну діяльність слідчих, у тому числі витребувати та перевіряти матеріали кримінальних проваджень, давати у них вказівки або оцінку прийнятим слідчим процесуальним рішенням [23]. Вважаємо, в деяких випадках надання вказівок позитивно впливає на рух досудового розслідування, зокрема, наприклад, у таких категоріях кримінальних проваджень як: 1) умисні вбивства, умисні тяжкі тілесні ушкодження, що спричинили смерть потерпілого, зґвалтування при обтяжуючих обставинах; 2) торгівля людьми; 3) незаконне виробництво, виготовлення, придбання, зберігання, перевезення, пересилання з метою збуту чи збут наркотичних засобів, психотропних речовин або їх аналогів; 4) дорожньо-транспортна пригода, у яких 
загинула хоча б одна особа або постраждало 5 і більше осіб; 5) кримінальні правопорушення, учинені організованими групами чи злочинними організаціями, бандитизм; 6) тяжкі та особливо тяжкі злочини, учинені у сфері службової діяльності; 7) злочини у сфері господарської діяльності, якими заподіяно матеріальної шкоди на суму понад мільйон гривень; 8) кримінальні правопорушення, які вчинені стосовно народних депутатів України, депутатів місцевих рад, працівників органів прокуратури, суду та представників засобів масової інформації; 9) тяжкі та особливо тяжкі злочини, учинені неповнолітніми або за їх участю; 10) кримінальні правопорушення, що викликали суспільний резонанс [23].

Також, досліджуваними положеннями КПК України встановлено повноваження керівника органу досудового розслідування (органу дізнання) вживати заходів щодо усунення порушень вимог законодавства у випадку їх допущення слідчим. Вважаємо, зазначене повноваження може бути віднесено як до організаційних, так і до процесуальних, тому що 3 одного боку усувати слідчого (дізнавача) є більш адміністративною функцією, але приводом для цього $є$ встановлення обставин, які перешкоджають проведення слідчим (дізнавачем) досудового розслідування (дізнання), що вже є проявом процесуальних повноважень (наприклад, вивчення матеріалів кримінального провадження, розгляд скарг учасників досудового розслідування тощо). 3 огляду на це, пропонуємо визначити також третю групу повноважень керівника органу досудового розслідування (органу дізнання) - організаційно-процесуальні, та віднести зазначене повноваження до запропонованої категорії.

Недоліком кримінального процесуального законодавства вважається відсутність в КПКУкраїни положення, яке би передбачало право керівника органу досудового розслідування витребувати кримінальні провадження у слідчих підпорядкованих підрозділів. Проте така практика існує з метою вивчення кримінальних проваджень і надання вказівок слідчим [24, c. 191].

Безумовно, вона є дискусійним моментом при здійсненні відомчого контролю за проведенням слідчих (розшукових) дій. Зазначене передбачено Інструкцією з організації діяльності слідчих підрозділів Національної поліції України, затвердженої наказом МВС України від 06.07.2017 № 570. Але в багатьох випадках таке втручання не $\epsilon$ виправданим, адже це призводить до тяганини під час розслідування, а в деяких випадках навіть порушує право на захист. Так, наприклад, у кримінальному провадженні, що розслідується Обухівським РУП ГУНП в Київській області за ознаками кримінального правопорушення, передбаченого ч. 2 ст. 15, п. 1 ч. 2 ст. 115 КК України, захисником подано клопотання про ознайомлення з матеріалами кримінального провадження, але йому надано відповідь, що матеріали кримінального провадження витребувані і знаходяться в СУ ГУНП в Київській області, тому на теперішній час надати їх для ознайомлення не видається можливим. Вважаємо, така ситуація $\epsilon$ порушенням права на захист. Вивченням матеріалів інших кримінальних проваджень встановлено, що такі випадки є непоодинокими й витребувані матеріали можуть знаходитися на вивченні у керівників органів досудового розслідування декілька місяців, адже граничних строків для такого 
вивчення ані законодавством, ані відомчими нормативними актами не встановлено. Як слушно з цього приводу зазначив Р.Г. Ботвинов, недоречне втручання керівників слідчих підрозділів вищого рівня призводить до втрати часу на розслідування, знижується наступальність розслідування. Так, 32\% слідчих одним з недоліків вказали застосування процесуального контролю керівниками слідчих підрозділів різних рівнів саме втрату часу провадження [25, с. 4]. Також в доктрині кримінального провадження наголошується на інших невизначених питаннях, зокрема: 1) невизначеність приводів та підстав; 2) невизначеність щодо моменту та строків перевірки; 3) невизначеність допустимої кількості таких перевірок [26, с. 134-135]. Зрозуміло, що в кожному конкретному випадку це повинно вирішуватися з урахуванням всіх обставин досудового розслідування, але правова визначеність деяких аспектів сприяла би додержанню прав учасників кримінального провадження, а також засад кримінального провадження.

Щодо порушення під час відомчого контролю меж процесуальної самостійності слідчого при проведенні слідчих дій зазначимо, що в доктрині кримінального процесу ними пропонується вважати: 1) право керівника органу досудового розслідування відсторонювати слідчого від проведення досудового розслідування з власної ініціативи або за ініціативи прокурора, за наявності підстав, передбачених КПК для відводу, або у разі неефективного досудового розслідування; 2) обов'язковість виконання слідчим письмових вказівок керівника органу досудового розслідування або прокурора; 3) «потрійний контроль» за діяльністю слідчого з боку керівника органу досудового розслідування, прокурора, слідчого судді [27, с. 414-415].

Вважаємо, що в даному випадку необхідно підтримувати баланс між доцільністю відомчого контролю й ступенем втручання суб'єктами його здійснення у досудове розслідування та процесуальною самостійністю слідчого або дізнавача. В будь-якому випадку, це повинно сприяти виконанню завдань кримінального провадження та додержанню прав і законних інтересів його учасників.

Висновки. Такимчином, відомчий контрольявляє собоюуправлінську функцію керівників органів дізнання або досудового розслідування з метою виконання завдань кримінального провадження, додержання прав і свобод учасників дізнання та досудового розслідування, визначення законності дій слідчого або дізнавача, а також недоліків у здійсненні досудового розслідування з метою якнайшвидшого їх усунення. Відомчий контроль в системі гарантій забезпечення прав, свобод та законних інтересів особи під час проведення слідчих (розшукових) дій $є$ важливим засобом дотримання конституційних прав і свобод людини під час досудового розслідування та реалізації засад кримінального провадження.

\section{СПИСОК ВИКОРИСТАНИХ ДЖЕРЕЛ}

1. Конституція України від 28 червня 1996 р. URL: http://zakon1.rada. gov.ua/laws/show/254к/96-ВР.

2. Скакун О.Ф. Теорія права і держави. Підручник. 2-ге видання. К.: Алерта, 2011. 520 с. 
3. Загальна теорія держави та права : підручник для студентів юридичних вищих навч. закладів / М.В. Цвік, О.В. Петришин, Л.В. Авраменко та ін. Харків: Право, 2011. 584 с.

4. Рабинович П. М. Права людини і громадянина у Конституції України (до інтерпретації вихідних конституційних положень). Харків: Право, 1997. $154 \mathrm{c}$.

5. Аверченко А. К. Подозреваемый и реализация его прав в уголовном процессе: дисс. ... канд. юрид. наук: 12.00.09. Томск, 2001. 237 с.

6. Словник української мови в 11 томах: за заг. ред. І. Білодіда . Т. 2.: уклад. А.А. Бурячок, В.М. Білоноженко, А.П. Білоштан та ін. К.: Наукова думка, 1971. 746 с.

7. Великий тлумачний словник сучасної української мови (з дод. і допов.) / Уклад. і гол. ред. В.Т. Бусел. К.: Ірпінь ВТФ Перун», 2005. 1728 с.

8. Строгович М.С. Основные вопросы советской социалистической законности. М., 1966. 252 с.

9. Погорецький М.А. Поняття кримінально-процесуальних гарантій. Часопис Національного університету «Острозька академія». Серія «Право». 2014. № 2(10). URL: http://lj.oa.edu.ua/articles/2014/n2/14pmakph.pdf.

10. Кримінальний процес: підручник / за заг. ред. В.Я. Тація. Х.: Право, 2013. 824 с.

11. Уголовный процесс: учебник для студентов юридических вузов и факультетов / В.И. Басков, К.Ф. Гуценко, М.А. Ковалев и др.; под ред. К.Ф. Гуценко. М.: Зерцало, 1997. 575 с.

12. Алексеев Н.С. Очерк развития науки советского уголовного процесса. Воронеж: Изд-во Воронежского ун-та, 1980.

13. Введенська В.В. Кримінально-процесуальні гарантії реалізації права на юридичну допомогу осіб, постраждалих від злочину: автореф. дис. ... канд. юрид. наук: 12.00.09. Київ, 2009.

14. Кучинська О.П. Поняття гарантій забезпечення прав учасників кримінального провадження. Адвокат. 2012 . № 7 (142). С. 4-8.

15. Добровольская Т.Н. Гарантии прав граждан в уголовном судопроизводстве. Советское государство и право. 1980. № 2. С. 134-137.

16. Лобойко Л.М. Методи кримінально-процесуального права : монографія. Дніпропетровськ, 2006. 437 с.

17. Словник української мови в 11 томах : за заг. ред. І. Білодіда . Т.4.: уклад. А. А. Бурячок, В. М. Білоноженко, А. П. Білоштан та ін.. К.: Наукова думка, 1973. 746 с.

18. Колеснік Г.Р. Функціональне призначення нагляду і контролю у досудовому розслідуванні: дис. ... канд. юрид. наук: 12.00.09. Харків, 2018. 224 с.

19. Малиновський В.Я. Державне управління. Навчальний посібник. К. Атіка, 2003. 576 с.

20. Кримінальний процесуальний кодекс України від 13.04 .2012 № 4651-VI. URL: http://zakon2.rada.gov.ua/laws/show/4651-17.

21. Степанов А.Б. Співвідношення прокурорського нагляду, відомчого та судового контролю під час досудового розслідування: дис. ... канд. юрид наук: 12.00.09. Харків, 2018. 235 с. 
22. Бабенко B.I. Прокурор у галузі охорони довкілля: сутність, повноваження, організація. Навчальний посібник. К. : ІН Юре, 2005. 408 с.

23. Інструкція 3 організації діяльності слідчих підрозділів Національної поліції України, затв. наказом МВС України від 06.07.2017 №570. URL: https://zakon.rada.gov.ua/laws/show/z0919-17\#Text.

24. Узагальнення судової практики 3 питань розгляду слідчим суддею клопотань про застосування заходів забезпечення кримінального провадження: Лист ВССУ від 07.02.2014 p. URL: https://ips.ligazakon.net/ document/VRR00135.

25. Ботвінов Р.Г. Визначення меж предмету відання керівника органу досудового розслідування, що здійснює контроль за додержанням податкового законодавства. Часопис Національного університету «Острозька академія». Серія «Право». 2013. №1(7). С. 1-13.

26. Баулин О.В. Ведомственный контроль и процессуальная независимостьследователя. ВестникДнепропетровского государственного университета. Правоведение. Вып. 3. непропетровск: Изд-во ДГУ, 1996. С. 131-137.

27. Зайцев О.В. Щодо процесуальної самостійності та незалежності слідчого в його процесуальних діях за кримінальним процесуальним законодавством України. Актуальні питання протидії злочинності у сучасних умовах: матеріали II Міжнародної науково-практичної конференції (ДДУВС, 15.03.2018). С. 414-416.

\section{Ya. Koniushenko}

\section{DEPARTMENTAL CONTROL IN THE SYSTEM OF GUARANTEES OF THE RIGHTS OF THE PERSON UNDER TIME OF INVESTIGATIVE (SEARCH) ACTIONS}

The article defines doctrinal approaches to the concept of «ensuring human rights and freedoms». It is established that the sphere of criminal proceedings is the one in which the constitutional rights and freedoms of a person are most narrowed and may be violated, as the activity of pre-trial investigation bodies is connected with the application of human rights restrictions and in certain cases. Based on this, it is proposed to define the provision of human rights and freedoms in criminal proceedings as the activities of authorized bodies (pretrial investigation, prosecutor's office, court), aimed at preventing violations of the rights and freedoms of each participant in criminal proceedings, human rights monitoring and protection of violated rights. Regarding the definition of guarantees of the rights of participants in criminal proceedings during investigative actions, the author concluded that they are an integral part of the guarantees of criminal proceedings as a whole. Such guarantees are aimed at ensuring the implementation of the tasks of criminal proceedings, implementation of its principles, observance of due process and prevention of violations of the rights and freedoms of participants in investigative (search) actions and, if necessary, help restore violated rights of participants in criminal proceedings. Departmental control over the conduct of investigative (search) actions is considered as one of the main guarantees of ensuring the rights, freedoms and legitimate interests of 
the person. It is proposed to define departmental control as a managerial function of heads of bodies of inquiry or pre-trial investigation in order to fulfill the tasks of criminal proceedings, observance of rights and freedoms of participants of inquiry and pre-trial investigation, determination of legality of actions of investigator or investigator and shortcomings in pre-trial investigation. A number of problematic issues during the departmental control over the investigator's and investigator's actions are outlined, in particular, regarding the provision of instructions, requesting materials of criminal proceedings by the head of the inquiry body or pre-trial investigation, the balance of powers of investigator and head of pretrial investigation body. Based on the study, it is proposed to amend the Criminal Procedure Code of Ukraine.

Keywords: departmental control; investigative (search) actions; ensuring human rights and freedoms; guarantees of ensuring the rights, freedoms and legitimate interests of the person. 